\title{
DIONYSOS SATELLITE OBSERVATORY AND HIGHER GEODESY LABORATORY: HISTORY AND PERSPECTIVES
}

\author{
Marinou A., Anastasiou D., Papanikolaou X., Paradissis D. and Zacharis V. \\ National Technical University of Athens, School of Rural and Survey Engineering, Dionysos \\ Satellite Observatory, Higher Geodesy Laboratory
}

\begin{abstract}
Dionysos Satellite Observatory and Higher Geodesy Laboratory have been in operation since the 60s and their main objective is to fulfill academic and research needs, determined through the ongoing scientific and technological advance in the field of geodesy. They are involved in all scientific domains related to the determination of earth's size and figure, as well as its temporal variations. Their field of expertise is Satellite Geodesy, (spanning a wide range of applications like reference systems, tectonic geodesy, etc.), as well as the study of the geoid and earth's gravity field. Keywords: Tide Gauges, Gravity, GPS.

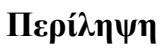

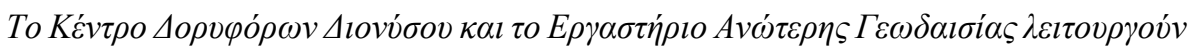

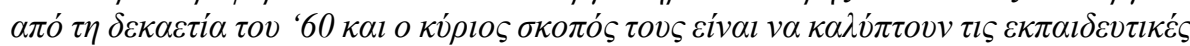

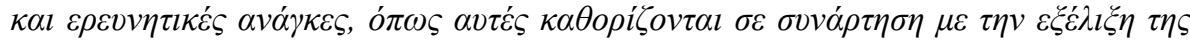

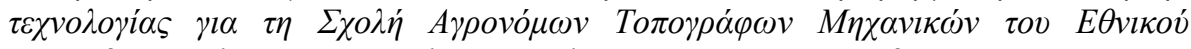

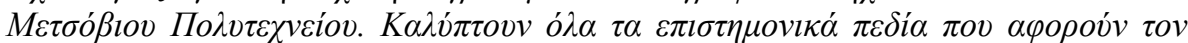

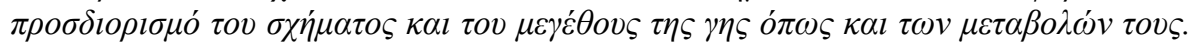

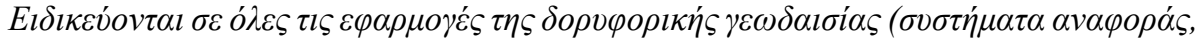

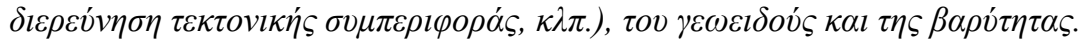

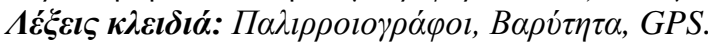

\section{Background of the laboratories}

Dionysos Satellite Observatory (DSO) is located in Dionysos, Attiki and its facilities are established within an area of $36000 \mathrm{~m}^{2}$ (Figure 1).

Dionysos Satellite Observatory has been actively involved in the evolution of Satellite Geodetic techniques, that took place throughout the last six decades; (Cocard et al., 1999; Reilinger, et al., 2000; McClusky et al., 2006; etc.). Instrumentation related to this activity is available in the laboratory's facilities (Figure 2, Figure 3). A permanent Laser Ranging System (SLR) and a BakerNunn camera one of the few used worldwide, were established in the 60s, for the determination of satellite orbits, and the realization of global reference frames. The first pillar of "zero order" has been established at DSO and used for the realization of the national reference frame and for cartographic connections with other European countries. 


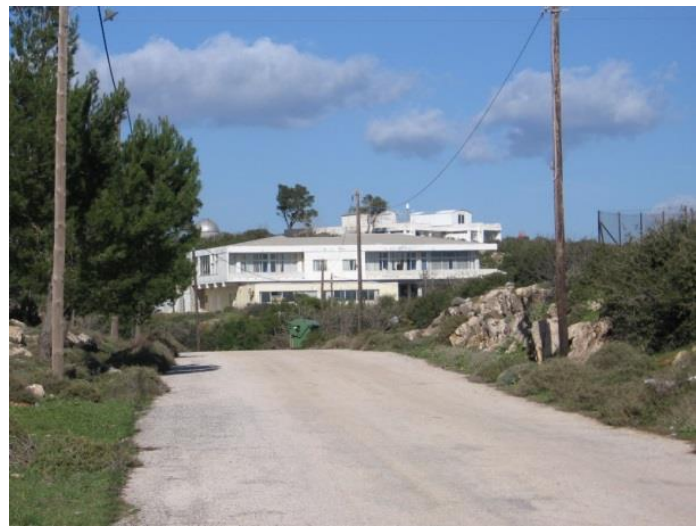

Figure 1 - Dionysos Satellite Observatory.
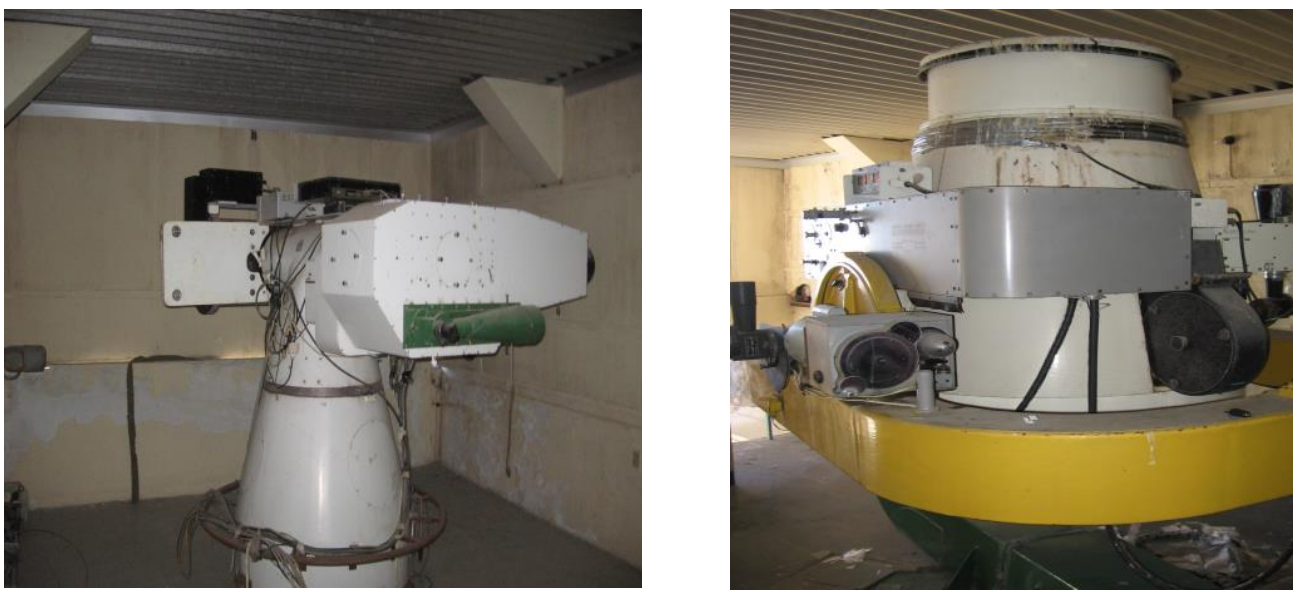

Figure 2 - Satellite Laser Ranging.

Higher Geodesy Laboratory (HGL) is located in the Campus of the National Technical University of Athens. Accordingly with Dionysos Satellite Observatory plenty of equipment used for measuring angles and distances on the surface of the earth following evolution of technology during the last decades is available.

Since their establishment, both laboratories have been in close collaboration with each other (sharing personnel and equipment) as well as with various international and national institutes and organizations, contributing to large-scale scientific projects. Since mid 80 's, one of the main scientific tasks of the laboratories has been studying tectonic deformation of the earth's crust via satellite techniques. More than 1000 GPS sites have been installed and measured, often in collaboration with other institutions (Oxford University, Insitut de Physique du Globe de Paris, France, Massachusets University of Technology etc.). These points form various networks and in their great majority cover seismically active regions (e.g., Corinth Rift, Ionian Sea, etc.) (Figure 4). Since the mid 90's, technological evolution enabled the installation of continuous GPS (cGPS) stations for geodetic and tectonic purposes. In Figure 5 all the cGPS networks installed by DSO and HGL in cooperation with Oxford University and Swiss Federal Institute of Technology are depicted. DSO and HGL don't own the equipment installed but participated at the installation and the maintenance of the cGPS network and are working with the available data. 


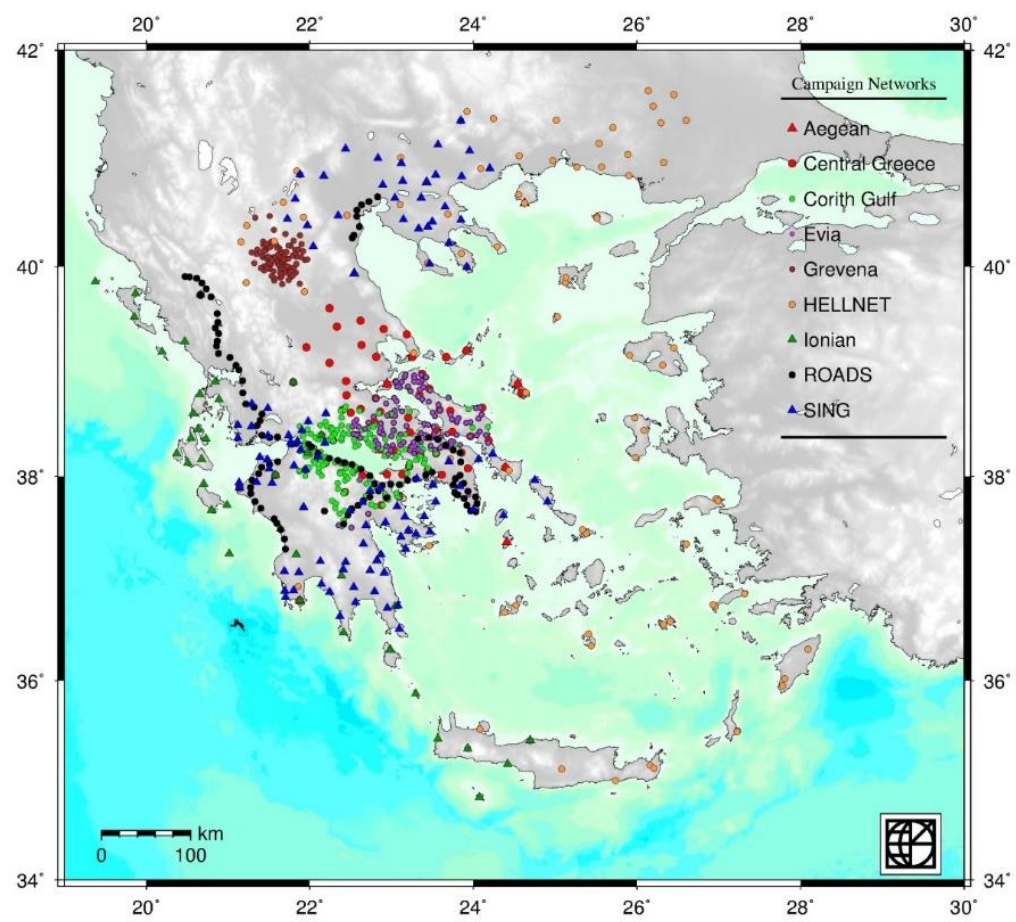

Figure 3 - Local GPS Networks, that have been periodically measured since mid 80's in cooperation with various institutes and Universities (Oxford University, Insitut de Physique du Globe de Paris, France, Massachusets University of Technology etc.).

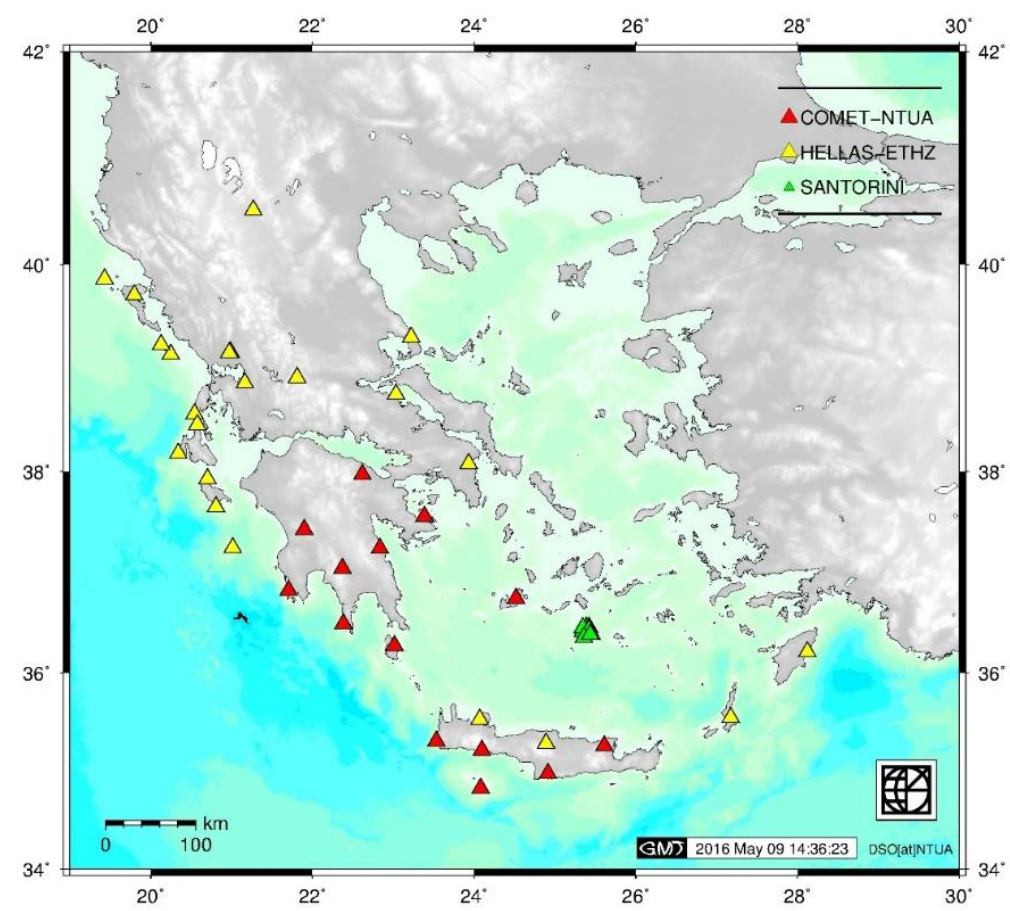

Figure 4 - Continuous GPS Networks that have been installed by Oxford University and Swiss Federal Institute of Technology in cooperation with DSO and HGL. 


\section{Available infrastructure - Objectives - Methods}

\subsection{Satellite Geodesy - Global Navigation Satellite Systems}

The evolution of Satellite Geodetic techniques such as Global Navigation Satellite Systems (GNSS) etc. has greatly enhanced the accuracy and quality of positioning and navigation on and/or near the Earth's surface. Apart from common surveying applications, great opportunities on the determination of global reference frames, tectonic motion and large scale cartographic applications are nowadays possible. Since their establishment Dionysos Satellite Observatory \& Higher Geodesy Laboratory are occupied mainly with Satellite Geodesy and its applications. A number of GNSS antenna/receivers, owned by the laboratories, are situated in well-established cGPS sites. The remaining equipment, is used to accommodate academic services; often these include re-occupation of campaign sites throughout Greece, or monitoring structural deformation. Three different types of GPS receivers are used at Dionysos Satellite Observatory. One of them is the first permanent GPS Station in Greece installed in 1995. In 2011, a cGPS station was established and is part of the network maintained by the International GNSS Service (IGS) (Figure 6); a third one was installed in cooperation with Oxford University.

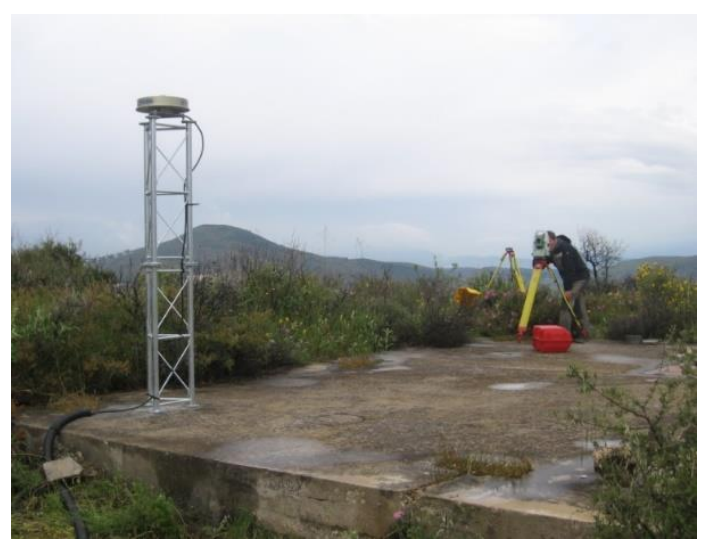

Figure 5 - IGS station at Dionysos Satellite Observatory.

Currently, three high-accuracy scientific software packages are available for the processing of all kinds of GPS data within the laboratories. The software can be purchased or requested from the corresponding institutes that developed them Bernese GNSS Software v.5.2 (Dach et al., 2007), GAMIT/GLOBK v.10.6 (Dong et al., 1998) and GIPSY/OASIS v.6.3 (Zumberge et al., 1997). High expertise is confirmed through various scientific projects during the last decades, especially with Bernese software (Clarke et al., 1997; Ganas et al., 2013; etc.). Several commercial-oriented software packages are in use, mostly to support educational needs. Highly experienced personnel and $\mathrm{PhD}$ students keep developing supporting routines for the processing of data and the evaluation of the results.

\subsection{Gravimetry}

Gravity and gravitation belong to the fundamental forces of physics and are essential for the determination of earth's shape and figure. The applications of gravimetry are numerous: navigation, various types of high-precision calibration, geo-exploration, etc. They all depend, in one way or another, on the precise knowledge of the Earth's gravity field, that is, on the results of space and terrestrial gravimetry (and associated surveys) as obtained from borehole or various types of classical terrestrial gravimeters, as well as from space (satellite) observations.Two high precision gravimeters are available for both DSO and HGL. An analog Lacoste - Romberg model G (Figure 7), as well as a digital Sintrex CG-5 and Autograv (Figure 8). There's also a gravity control tunnel at DSO used to calibrate the instruments. 

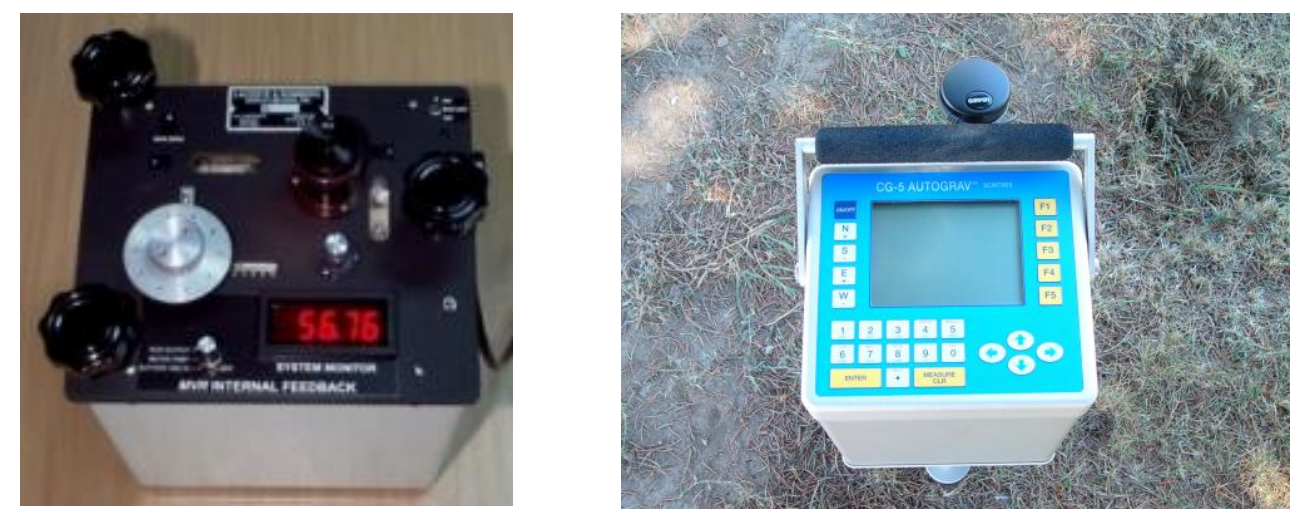

Figure 6 - Lacoste - Romberg model G Gravity Meter.

\subsection{Tide Gauges}

Monitoring long or short term temporal sea level variations is fundamental in many research fields, and for a variety of reasons. The obvious ones are related to the direct effect of the oceans (the sea) in the lives of the people, such as the climate change or the tsunami hazard. Others, such as geoid evaluation and height reference frames, have indirect effects. At the moment, 7 tide gauges (Figure 7) are installed at suitable locations, most of them co-located with GNSS receivers or other instrumentation (seismometers, accelerometers, etc.), forming a rather sparse network throughout the Greek seas.

Data from these sensors are collected, evaluated, and stored on a daily basis.

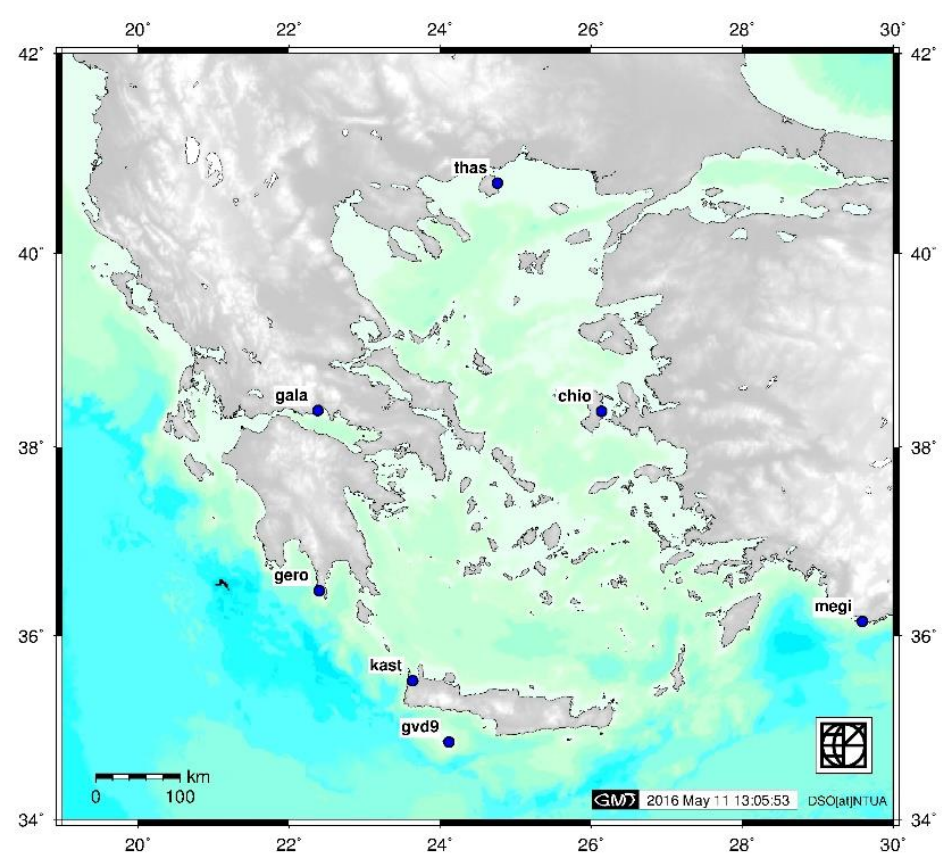

Figure 7 - Tide Gauges Network. 


\subsection{Inertial measurement unit (IMU)}

An inertial measurement unit (IMU) is an electronic device that measures and reports a craft's velocity, orientation, and gravitational forces, using a combination of accelerometers and gyroscopes, sometimes also magnetometers. IMUs are typically used to manoeuvre aircrafts, including satellites and landers. Recent developments allow for the production of IMU-enabled GPS devices. An IMU allows a GPS receiver to work when GPS-signals are unavailable (e.g. in tunnels, inside buildings, etc.), or when electronic interference is present. The Laboratories own an IMU mainly used for navigation research and applications.

\subsection{Synthetic Aperture Radar}

Synthetic-Aperture Radar (SAR) is a form of radar which is used to create images of objects, such as landscapes; these images can be either two or three dimensional representations of the object. SAR uses the motion of the radar antenna over a targeted region to provide finer spatial resolution than is possible with conventional beam-scanning radars. The commercial Gamma Software (Gamma RS, 2015) is available to the laboratories for processing SAR data, as well as several other types of open source software for the same propose. SAR can be used to serve a wide range of scientific aims, related to remote sensing, such as climate change, environment, resources, natural hazards, etc. The main focus for the laboratories, is the integration of GNSS and SAR to accurately detect three dimensional tectonic deformation, as SAR offers high accuracy results for elevation (Papoutsis et al., 2013).

\section{Services and products}

The last 3 years, all the available cGPS stations in Greece (Figure 8) are processed with Bernese GNSS Software v.5.2, on a routine basis. We process all data available in the public domain, data managed by the laboratories and data provided by surveying companies. Position time series are stacked for all stations and made available via the DSO website (http://dionysos.survey.ntua.gr/2. In Figure 9 the position time-series for station VLSM is depicted. An offset due to the major seismic event on 26/01/2014 can be easily observed. For all major seismic events, in the vicinity of which cGPS stations were installed (e.g. Lemnos, Kephalonia), seismic motion was observed with this method just after the event.

Products from the routine analysis include coordinate estimates, atmospheric monitoring (tropospheric refraction, iononospheric delay) and a wide variety of GNSS-specific result files (e.g. SINEX).Figure 12 depicts a snapshot of a map of ionospheric total electron content (TEC, see http://dionysos.survey.ntua.gr/dsoportal/_projects/IonoRemSens/).

The laboratories use GSAC software (UNAVCO GSAC, 2015) to host geodetic-type data and products. GSAC provides a web browser-based user interface (UI) for data search, data file downloading, and database querying. Data from several GNSS stations can be retrieved using this application through the web site of DSO that presents the scientific work of both laboratories. 


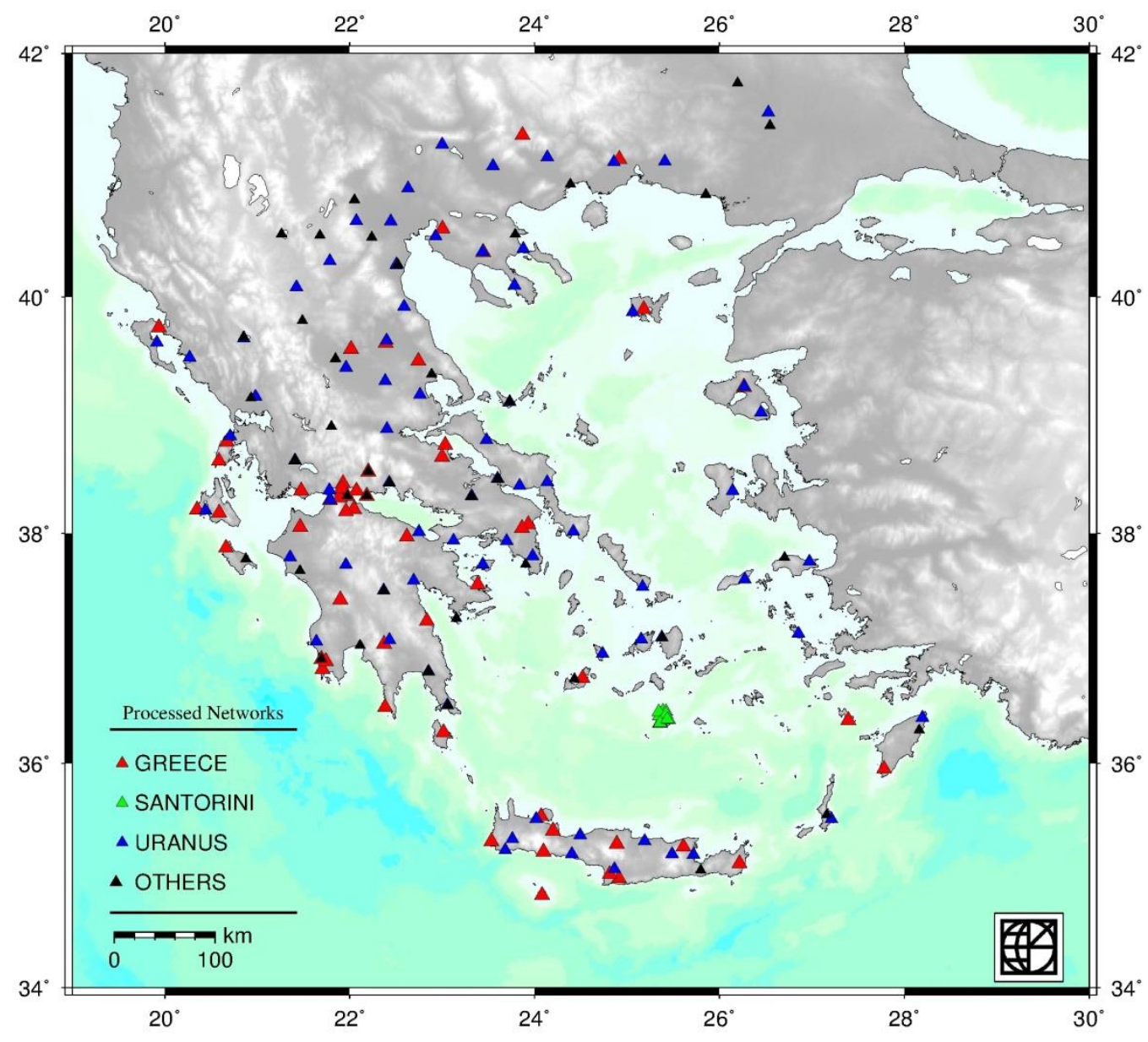

Figure 8 - Processed GPS Networks. Data available in the public domain, data managed by the laboratories and data provided by surveying companies (National Observatory of Athens Network, National University of Athens, National University of Patras, Aristotle University of Thessaloniki, Technical University of Crete, Unavco, Massachusets University of Technology, Tree Company Network).

\section{Current and future research}

The laboratories (DSO, HGL) aim in continuing to get actively involved and contributing to the GNSS community; towards that end, efforts are undertaken to join EUREF as a GNSS Analysis Centre. In addition, there is an ongoing effort to re-operate all the cGPS stations in South Aegean, within the framework of the "South Aegean Geodynamic and Tsunami Monitoring Platform" project. All available details about the project can be found at the web page http://dionysos.survey.ntua.gr/SEISMO/index.html. Moreover, a project for developing in-house software for the acquisition, monitoring and analysis of tide gauge data is highly active within DSO. This will provide near-real-time analysis capabilities, which will in turn allow the development of a tsunami early warning system. Following all the up-to-date techniques in GNSS processing, modelling of tectonic motion, and strain calculation as well as improving and archiving all available data and results is one of the constant tasks of the laboratories. 


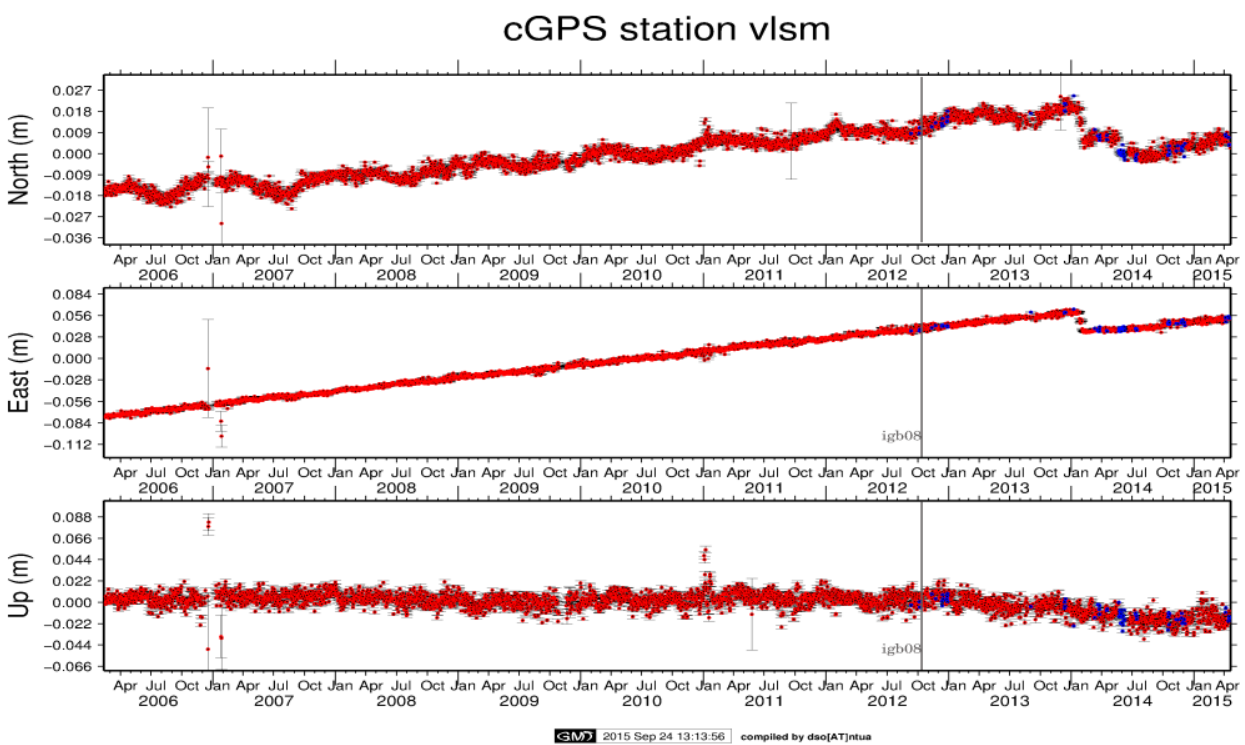

Figure 9 - Time series for cGPS station VLSM in Kephallonia in north, east, up components.

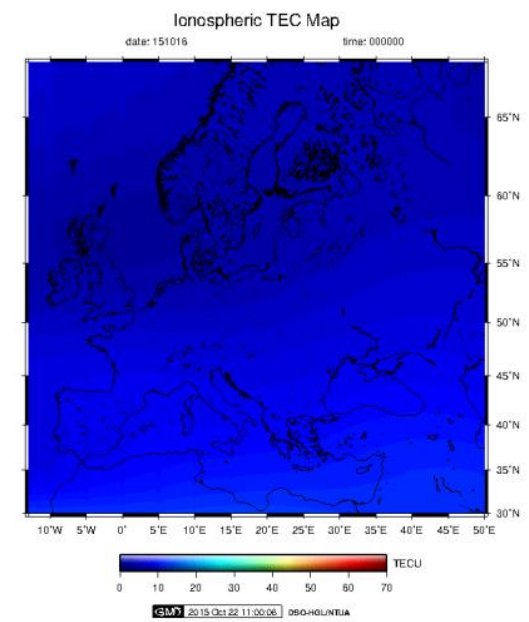

Figure 10 - Regional map of ionospheric total electron content (TEC).

\section{Acknowledgments}

We would like to thank the personnel of the laboratories during all these decades, academic, technical, administrative and students. They were and are the foundation of all the research and educational achievements. Then we would like to thank all the colleagues from several national and international institutions as Delft University of Technology, the Netherlands, University of Oxford, UK, Institut de Physique du Globe de Paris, France, University College London, UK, ETH Honggerberg, Switzerland, University of Newcastle upon Tyne, UK, Massachusetts Institute of Technology USA, National Observatory of Athens, Hellenic Military Geographical Service, Hellenic Navy Hydrographic Service. Through these collaborations a significant amount of data has been collected and led to very interesting scientific results.

Finally we would like to thank all the GNSS data providers for this study. GNSS data for URANUS network provided by Tree Company Co. 


\section{References}

Clarke, P.J., Paradissis, D., England, P.C., Parsons, B.E., Billiris, H., Veis, G. and Ruegg, J.C., 1997. Geodetic investigation of the 13 May 1995 Kozani - Grevena (Greece) earthquake, Geophys. Res. Lett., 24(7).

Cocard, M., Kahle, H., Peter, Y., Geiger, A., Veis, G., Felekis, S., Paradissis, D. and Billiris, H., 1999. Earth Planet Sci Lett., 172(1-2), 39-47.

Dach, R., Hugentobler, U., Fridez, P. and Meindl, M, 2007. New constraints on the rapid crustal motion of the aegean region: Recent results inferred from GPS measurements (1993-1998) across the west hellenic arc, Greece, Bernese GPS Software Version 5.0, Astronomical Institute, University of Bern.

Dong, D.N., Herring, T.A. and. King, R.W., 1998. Estimating regional deformation from a combination of space and terrestrial geodetic data, J. Geodesy, 72, 200-214.

Ganas, A., Marinou, A., Anastasiou, D., Paradissis, D., Papazissi. K., Tzavaras, P. and Drakatos, G., 2013. Derived estimates of crustal deformation in the central and North Ionian Sea, Greece: 3-yr results from NOANET continuous network, Journal of Geodynamics, 67.

GAMMA REMOTE SENSING, GAMMA Remote Sensing Research and Consulting AG, http://www.gamma-rs.ch/gamma.html (last accessed Oct. 2015).

McClusky, S., Balassanian, S., Barka, A., Demir, C., Ergintav, S., Georgiev, I., Gurkan, O., Hamburger, M., Hurst, K., Kahle, H., Kastens, K., Kekelidze, G., King, R., Kotzev, V., Lenk, O., Mahmoud, S., Mishin, A., Nadariya, M., Ouzounis, A., Paradissis, D., Peter, Y., Prilepin, M., Reilinger, R., Sanli, I., Seeger, H., Tealeb, A., Toksöz, M.N. and Veis, G., 2000. Global positioning system constraints on plate kinematics and dynamics in the eastern mediterranean and Caucasus, Journal of Geophysical Research B: Solid Earth, 105(B3), 5695-719.

Papoutsis, I., Papanikolaou, X., Floyd, M., Ji, K.H, Kontoes, C., Paradissis, D. and Zacharis, V., 2013. Mappinginflation at Santorini volcano, Greece, using GPS and InSAR, Geophysical Research Letters, 40(2), 267-272, doi: 10.1029/2012GL054137.

Reilinger, R., McClusky, S., Vernant, P., Lawrence, S., Ergintav, S., Cakmak, R., Ozener, H., Kadirov, F., Guliev, I., Stepanyan, R., Nadariya, M., Hahubia, G., Mahmoud, S., Sakr, K., ArRajehi, A., Paradissis, D., Al-Aydrus, A., Prilepin, M., Guseva, T., Evren, E., Dmitrotsa, A., Filikov, S.V., Gomez, F., Al-Ghazzi, R. and Karam, G., 2006. GPS constraints on continental deformation in the africa-arabia-eurasia continental colliszone and implications for the dynamics of plate interactions, Journal of Geophysical Research B: Solid Earth, 5.

Sykioti, O., Kontoes, C.C., Elias, P., Briole, P., Sachpazi, M., Paradissis, D. and Kotsis, I., 2003. Ground deformation at Nisyros volcano (Greece) detected by ERS-2 SAR differential interferometry, International Journal of Remote Sensing, 24(1), 183-188.

UNAVCO GSAC WS: Web Services for Geodesy Data Repositories, http://www.unavco.org/software/data-management/gsac/gsac.html (last accessed Oct. 2015).

Zumberge, J.F., Heflin, M.B., Jefferson, D.C., Watkins, M.M. and Webb, F.H., 1997. Precise point positioning for the efficient and robust analysis of GPS data from large networks, J. Geophys. Res., 102(B3), 5005-5017, doi: 10.1029/96JB03860. 